\title{
BARÁTOK TAVA \\ TÁJRÉGÉSZETI ÉS TÖRTÉNETI ADATOK EGY HELYNÉV EREDETÉHEZ*
}

\author{
K. NÉMETH ANDRÁS*
}

\begin{abstract}
A közlemény a Tolna megyei Kisszékely határában található Barátok tava nevü tó nevének eredetét magyarázza meg, tájrégészeti és történeti adatok segitségével. Egy 1518-as adat szerint a simontornyai domonkos kolostor két halastavat kapott Temerkény pusztán. A Barátok tava mellett fekvö középkori faluhelyet okleveles adatok alapján sikerült azonositani az elpusztult Temerkény helyével, így feltételezhetö, hogy a tó és közelében fekvő Csádés-tó lehetett a simontornyai domonkos 'barátoknak' adományozott két halastó.
\end{abstract}

Kulcsszavak: középkor, Kisszékely, halászat, halastó, helynevek, környezettörténet, kolostori gazdálkodás

A Tolna megyei Hegyhát északi részén fekvő Kisszékely település északi szélén található a Barátok tava nevü népszerü horgásztó. Keletkezését az ismeretlen eredetü helyi hagyomány szerzetesekkel hozza kapcsolatba. Ennek legkorábbi megfogalmazását 1938-ból ismerem, Kiss István így ír erről simontornyai helytörténeti monográfiájában: „A mai Kisszékely (...) 1571-ben »Beraten-szigel « (Barátszékely). Erre utal a még most is használt Barátok tava helynév, melynek eredete Buzlay Mózesig vezethetö vissza, ki itt két ma is létezö halastavat ajándékozott a prédikáló szerzeteseknek."1 A tó közelében, tőle nyugatra fekvő erdőben található a Barátok pincéje vagy Barátok barlangja, amelyet a hagyomány szerint a törökök hagytak itt. ${ }^{2} \mathrm{Az}$ efféle névmagyarázatok, amikor a helyi lakosok a helynevekböl „,következtették ki” azok eredetét, a magyar nyelvterület egészére jellemzőek. ${ }^{3}$ A helynevünkhöz hasonló, a birtokos nevéhez kapcsolt -tava utótaggal képzett földrajzi nevek a középkor óta elterjedtek, pl. a kimerítően feldolgozott Szabolcs megyében a középkorban Apáttava, Ispántava, Páldeák-tava, Pap-tava, Prépost-tava, Úr-tava nevü tavak léteztek. ${ }^{4} \mathrm{~A}$ Barátok tava helynév kapcsán is felmerülhet a középkori eredet, 'barát' szavunk 'szerzetes' jelentése ekkorra már régen kialakult. ${ }^{5}$

A kisszékelyi Nagy-árok (vagy Kisszékelyi-árok, a 19. századi kataszteri térképen Wassergraben) eredeténél, annak két ágán létesített, V-alakú Barátok-tava két szára közti, északnyugat-délkelet irányú félsziget kiváló adottságot biztosított a védett vízparton előszeretettel megtelepedő embernek minden történeti korban. 1996-ban lakossági bejelentés

\footnotetext{
* K. Németh András. Wosinsky Mór Megyei Múzeum, H-7100 Szekszárd, Szent István tér 26. A tanulmány az MTA Bolyai János Kutatási Ösztöndíj (BO/00003/12/2) és a Kubinyi András Középkortudományi Alapítvány támogatásával készült, amelyért ezúton is köszönetet mondok. Köszönöm továbbá a lelőhelyet bejelentő Oláh László (Simontornya) segítségét, adatait, Horváth Andrásnak és Isztl Mártonnak (Kisszékely) a Barátok pincéjéhez történő kalauzolást, végül, de nem utolsósorban lektoromnak, Zatykó Csillának a kézirathoz füzött hasznos megjegyzéseit.

${ }^{1}$ KISS 1938, 74. Nem lehetetlen, hogy a mai is élő hagyomány éppen Kiss István müvén alapul. Egy horgászati honlap napjainkban pl. így jellemzi a tavat: „,500 éve a Ferences rendi szerzetesek, »barátok« által létesített, völgyzárógátas tó". http://www.horgasz.hu/page/54/art/54/akt/54/html/kisszekelyi-baratok-tava.html [a letöltés időpontja: 2012. november 16.]

2 TMFN 1981, 90: 10/59. - A Barátok pincéjét sikerült azonosítani az erdő szélén, de már csupán beszakadt bejáratának helye látszik, jellegéről és kiterjedéséről nem állapítható meg több. A szerző terepbejárása, 2013. márc. 3.

${ }^{3}$ MNL IV. 1981, 38.

${ }^{4}$ MIKESY 1940. 5, 14, 24, 26, 28.

5 TESz I. 246. Ugyanez a helynév megtalálható Jászfényszaru határában is, ahol a tó mellett Árpád-kori egyházas falu fekszik. LANGÓ 2006, 81.
} 
nyomán Ódor János Gábor bejárta a földnyelv keleti részét (az álló növényzet a nyugati oldal bejárását lehetetlenné tette). ${ }^{6} \mathrm{~A}$ tóhoz közelebb eső részen a vízzel párhuzamosan a lengyeli kultúra kerámia-töredékeit, vele átfedésben északabbra kb. 700 méter hosszan a rézkori péceli kultúra edénydarabjait figyelte meg. A keleti patakág mentén kisebb római megtelepedés régészeti nyomait is azonosította.

2012. novemberben, majd 2013. márciusban szintén lakossági jelzésre kerestem fel újra a lelőhelyet, amikor immár a dülö teljes területén, nyugaton egészen a nyugati patakágig sikerült megfigyelni a másfél évtizeddel korábban leírt kultúrák felszíni nyomait. A terepbejárás jelentőségét szempontunkból az adja, hogy a dűlő nyugati részén, a tó két ága által közrefogott félsziget kiemelkedő, északnyugat-délkelet irányú gerincén (1. ábra) néhány középkori kerámia-töredékeket is találtunk, a leletbejelentő Oláh László előzőleg pedig többszöri terepszemléjén számos középkori cserepet gyüjtött. A lelöhelyen középkori leletanyag létéről korábban nem volt tudomásunk, most tehát adott volt egy olyan középkori faluhely, amelyet meg kellett feleltetni a környék okleveles adatokból ismert, terepen nem azonosított középkori településeinek egyikével.

A környéken feküdt egy Temerki(n) nevü középkori település, amelynek emléke nem maradt fenn helyneveinkben, így pontos helyét a korábbi településtörténeti kutatásoknak nem sikerült meghatározni. Csánki Dezső az okleveles adatok alapján még „Pinczehely, Görbő, Miszla, Pálfa sat. vidékén" kereste, ${ }^{7}$ Engel Pál hasonló forrásokra támaszkodva pedig Pálfától nyugatra helyezte. ${ }^{8}$ Mint látni fogjuk, a lokalizálásban Dávid Géza jutott legközelebb a valósághoz a török defterek alapján, aki szerint az egykori falu a mai Kisszékely mellett feküdt. ${ }^{9}$

Tekintsük át röviden időrendben a Temerkény falura vonatkozó adatokat. A település neve puszta személynévből, magyar névadással keletkezett, az alapjául szolgáló ('vas' jelentésü, török eredetü) régi magyar Tömör név előzményéböl kicsinyítőbokorral alakult ki. ${ }^{10} 1335$-ben Apor nembeli Miklós és fiai, János, Pál, Máté eltiltották rokonukat, Fülöpöt három birtok, Apor (ma Pálfa-Csalános-dülő/Téglás-dülő), ${ }^{11} \mathrm{Kusd}^{12}$ és Temerkény (Themerken) eladásától, Ozorai Miklóst pedig azok megvételétől. ${ }^{13}$ 1361-ben Gyánt (ma Tolnanémedi-Gyántiföldek) ${ }^{14}$ határjárásban említik a Gyántról ide (Themerki) vezető utat. ${ }^{15}$ 1387-ben Zsigmond király a hütlen Apori Pál fia Gergely Aporban és Temerkényben levő (Temerky) két birtokrészét, összesen 20 népes jobbágytelket Báni Demeternek adta új adományul. ${ }^{16} 1421$ ben Apori Tamás - Apori Jakab fiai: Lőrinc, János és Tamás nevében - eltiltotta Apori Gergely özvegyét, Céli Mihályt és Ábeli Jakabot nevezett Gergely Apor, Temerkény (Themerky) és Petrőc (ma Kárász-Fekete-Petrőc) ${ }^{17}$ birtokrészeinek elidegenítésétőll. ${ }^{18} 1430$ ban Gyánt határjárásban két tölgyfa mellett határjeleket említenek, a keleti Temerkényé (Themerkyn). ${ }^{19}$ 1431-ben a Németiböl Temerkényre (Themerken) vezető út tünik fel Görbö

\footnotetext{
${ }^{6}$ Wosinsky Mór Megyei Múzeum Régészeti Adattára 553-96. (Kisszékely-Bernát-tanya, 1996. jún. 19.)

${ }^{7}$ CSÁNKI 1897, 455.

${ }^{8}$ ENGEL 2001.

${ }^{9}$ DÁVID 1982, 132.

${ }^{10}$ KISS 1998, II, 675.

${ }^{11}$ K. NÉMETH 2011, 133-134.

${ }^{12}$ Helye ismeretlen, Csánki a megyehatár környékén, a Sárvíz mentén kereste: CSÁNKI 1897, 436.

${ }^{13}$ AO III. 122. sz.; AOkl XIX. 347. sz.

${ }^{14}$ K. NÉMETH 2011, 167.

${ }^{15}$ FEJÉR IX/3. 267.

${ }^{16} \mathrm{ZsO}$ I. 293. sZ.

${ }^{17}$ K. NÉMETH 2011, 86.

${ }^{18} \mathrm{ZsO}$ VIII. 374. sz.

${ }^{19}$ FEJÉR X/7. 285.
} 
(ma Pincehely-Szentkút alja) ${ }^{20}$ határjárásában. ${ }^{21}$ 1462-ben Mátyás király Garai László nádor özvegyének és fiának, Jóbnak adományozta Pálfalva (ma Pálfa) és Temerkény birtokokat, amelyek Apori Fülöp magtalan halála folytán szálltak a koronára. ${ }^{22}$ 1518-ban Buzlai Mózes az általa alapított simontornyai domonkos kolostornak adta egyebek mellett Temerkényt is két halastóval (prediolum de Themerken cum duabus piscinis in eo existentibus). ${ }^{23} \mathrm{~A}$ defterekben a település Tömörkén néven szerepel 1565-ben, 1570-ben és 1580-ban, mindannyiszor pusztaként. $^{24}$

Az 1518-ban említett halastavakról nincsenek további adataink. A rövid életü, ekkortájt alapított simontornyai domonkos kolostor ${ }^{25}$ lakói legkésőbb Simontornya 1545-ös török elfoglalásáig élvezhették a tavak előnyeit. E halastavak a környék földrajzi adottságai alapján nem azok közé a halastónak nevezett, nagyszámú objektum közé tartoztak, amelyeket többnyire nagyobb folyók természetes kiöntésein létesítettek, ${ }^{26}$ hanem a völgytalpon, patakmeder kiszélesítésével és felduzzasztásával hozhatták létre őket. Az oklevélben említett két halastó közül az egyik a Barátok tavával azonosítható, a másik pedig talán a tőle délkeletre néhány száz méterre ma is létező, ugyanazon a patakon létesített Csádés-tóval feleltethető meg. Említésre méltó utóbbi neve is, hiszen a csádé egyik jelentése a sok közül 'sásféle, sás és káka', egy másik pedig 'vizenyős helyen termő, sással vegyes füféle', ${ }^{27}$ ami utalhat egy élö tó sekélyvízi növényzetére, vagy az elhagyott tómedrekben elöszeretettel tenyésző savanyú füfélékre is.

Mint láthattuk, a falu fekvésére nemcsak a vele azonos birtokügyekben szereplő települések környékére fókuszálva következtethetünk, de rendelkezünk néhány konkrét adattal is környezetére vonatkozóan. Gyánt határjárásából kiderül, hogy Gyántot keletröl Temerkény határolta, a simontornyai domokosnak adományozott birtokok felsorolásából pedig az, hogy határában halastavak is voltak.

A fenti adatokból következik, hogy összekapcsoljuk az írott forrásban Temerkény birtokon említett egykori halastavakat, valamint a terepen a Barátok-tava fölött régészetileg azonosított középkori lelőhelyet. A lelőhely fekvése megfelel az idézett határjáró oklevelek alapján kikövetkeztethető hozzávetőleges helynek, amennyiben valóban Gyánttól (dél)keletre és Görbőtől keletre helyezkedik el, közte és a két említett falu között pedig nem ismerünk más középkori faluhelyet. A Barátok tava helynév középkori eredete a fentiek után joggal feltételezhető, kevéssé valószínü, hogy a török kor után nevezték volna el utólag a tavat, vagy annak helyét.

Temerkénynek nem maradt helynévi emléke, az 1580-as defter után több említését nem ismerjük. Közelében, tőle néhány száz méterre északra, a Nagy-árok keleti ága forrásánál a 19. század közepe táján jelenik meg Csókáspuszta, ${ }^{28}$ amely nevének eredete nem ismert, a Pesty Frigyes-féle összeírásban 1864-ben még a dülők egyikeként szerepel. ${ }^{29}$ A tó feletti dülő neve a nyomon követhető elmúlt másfél évszázadban egyaránt Szoros, ${ }^{30}$ amelynek jelentése

${ }^{20}$ A szerző terepbejárása, 2012. nov. 29. A terepbejárási jelentés: Régészeti Kutatások Magyarországon 2012 (2013) megjelenés alatt.

${ }^{21}$ FEJÉR X/7. 380.

${ }^{22}$ MOL Diplomatikai Levéltár 15705.

${ }^{23}$ Kiadása: MREV IV. 257. CCCIII. sz. Regesztája: C. TÓTH 2000, 107. sz.. Említi: HARSÁNYI 1938, 92. - A domonkosok a Simontornyával szomszédos Igaron (Fejér m.) és a közeli Miszlán is rendelkeztek halastavakkal.

${ }^{24}$ DÁVID 1982, 132, 278, 294.

${ }^{25}$ Legújabban, további irodalommal: K. NÉMETH 2011, 140-141.

${ }^{26}$ Vö. legújabban: ZATYKÓ 2011, 399-400.

${ }^{27}$ ÚMTSz I. 734-735. A régiségben a 17. század elején 'csalit, cserjés' értelemben tűnik fel, 'sásféle' jelentése a 18. század közepétől adatolt. TESz I. 465.

28 MOL S 78 236. téka Kisszékely 001-020 (1859); http://www.archivportal.arcanum.hu/kataszter/; http://archivportal.arcanum.hu/maps/html/katfelm2b_google.html

${ }^{29}$ GAÁL - KÖHEGYI 1975, 322.

${ }^{30}$ TMFN 1981, 90: 10/43. 
'szük, meredek falú völgy, út' ${ }^{31}$ A dülő bizonyára a Barátok tava déli gátján keresztül vezető, alább tárgyalandó mélyútról kapta a nevét, aminek Szoros lehetett a helyi megnevezése, a mai helynév tehát a mélyen bevágódott dủlőutat jelölő helynév jelentésbővülése folytán válhatott egy nagyobb dülő elnevezésévé. ${ }^{32}$

A környéken nem szokatlan, hogy középkori falvak helynévi maradványok nélkül tünnek el, annál is inkább érdekes, hogy az elpusztult Temerkény falu egyik dülőneve fél évezred után is él. Erre éppen a közelben másik példánk is akad: a Temerkénnyel nyugatról határos Görbö 1431-es határjárásában említett Halyagoshát (Halyagoshat) nevü hely ${ }^{33}$ Hajagos néven ma is létezik. ${ }^{34}$ A tóneveknél maradva, a közeli Iregszemcse határában a 17. század végétől adatolt, ma is élö Bántava helynévről is valószínüsíteni lehetett, hogy azonos egy 1481-ben említett halastóval, amelynek névadója talán egyik birtokosa, Hédervári Imre macsói bán lehetett. ${ }^{35}$ Bár a víznevek állandósága leginkább a nagyobb folyóvizekre jellemző, ${ }^{36}$ kisebb állóvizek neve is fennmaradhatott, amelyhez esetünkben Kisszékely környéke máig tartó viszonylagos elzártsága is hozzájárulhatott.

Következő lépésként a Kisszékelyen napjainkban létező két tó - a Barátok tava és a töle délkeletre fekvő Csádés-tó - fizikai létét igyekszünk időben minél korábbra visszavezetni. Természettudományos vizsgálatok helyett itt most csak a környék térképi ábrázolásainak tanulmányozására vállalkozhatunk. A legkorábbi térkép, az 1780-as években készült első katonai felmérés már meglepetéssel is szolgál, hiszen a mai két halastavat ezen hiába keressük, viszont nagy kiterjedésü tavat jelölnek a Nagy-árok és a nyugati irányból bele torkolló Vadkerti-árok (a kataszteri térképen Vadvíz-árok) találkozásánál, ${ }^{37}$ ahol ellenben ma már nyoma sincs tónak. Bár a Barátok tava nem szerepel a térképen, figyelemre méltó, hogy pontosan a mai gátja vonalában ekkor út vezetett a patakon át, amelytől északra, a keleti patakág mentén - éppen a mai tó helyén - mocsaras, vizenyős területet jelölnek. Utóbbiban nem nehéz felismerni a tó helyét, az út pedig bizonyára a tavat lezáró gát tetején szelte át a patakot. Hogy ez a Temerkény falu helye mellett haladó út nem a török kiüzése és a térkép keletkezése közötti időszakban, hanem jóval korábban alakult ki, sejteti, hogy dél felé az erdőn keresztül a mai Nagyszékely központjába, a középkori templomhoz ${ }^{38}$ vezetett, ${ }^{39}$ észak felé pedig a Kisszékelyi-erdő nyugati széle mentén éri el Szentpéter-szőlőhegynél a Kapos déli felén haladó utat. Szentpéter szintén egyházas hely volt, helye azonosítatlan, de kétségtelenül a Temerkényt is érintő út északi végpontja környékén fekhetett. ${ }^{40}$ Szentpéter után északkelet felé az út néhány kilométer után Simontornyára ér, így a Temerkényben fogott halaknak a domonkos kolostorba történő szállítása nem okozott túlzott erőfeszítést. Az út régiségét mutatja, hogy az - amint a már említett Szoros dűlőnév is jelzi - mindkét irányban bevágódott, a Barátok tava közvetlen közelében pedig, a gát és Kisszékely északi széle közötti kb. 50 méteren 6-8 méter mélyen is (2. ábra).

A ma már nem létező harmadik tóról is feltételezhetjük a középkori eredetet, s mint ilyen, talán a déli gátja közelében nemrég azonosított Parasztszékely faluhoz ${ }^{41}$ tartozhatott, bár írott forrás nem maradt róla. Létéről ez az egyetlen forrásunk. (Az első katonai felmérés alapján

\footnotetext{
${ }^{31}$ TESz III. 786.

${ }^{32}$ Erre Máté Gábor hívta fel a figyelmemet, segítséget ezúton is köszönöm.

${ }^{33}$ FEJÉR X/7. 381.

${ }^{34}$ TMFN 1981, 89: 9/237.

${ }^{35}$ K. NÉMETH 2002.

${ }^{36}$ Erre legújabban: GYÖRFFY 2010, 129-130.

${ }^{37}$ EKF Coll. XII. Sect. 27.

${ }^{38}$ Ld. K. NÉMETH 2011, 113-114.

${ }^{39}$ Helyi adatközlőm, Isztl Márton szerint az utat 'országútnak' nevezték, és néhány évvel ezelőttig - amikor az erdő kerítésével kettévágták - ezen jártak Kisszékelyből Nagyszékelybe.

${ }^{40}$ K. NÉMETH 2011, 168.

${ }^{41}$ Uo. 90.
} 
valószínünek látszik, hogy Temerkény és Parasztszékely között valahol a Csádés-tó és e harmadik tó között húzódott a középkori faluhatár.)

A környék következő ábrázolása közel száz évvel későbbről származik. Az 1819 és 1869 között készült második katonai felmérésen, ${ }^{42}$ az 1859-ben készült kataszteri térképen, ${ }^{43}$ csakúgy, mint 1950-ben Kisszékelyen kizársaólag a Csádés-tó létezett, ${ }^{44}$ amely az 1970-es években végzett dülőnévgyüjtés szerint nem funkcionált, ekkor Kenderáztatónak is mondták. ${ }^{45}$ Egy 1977-es térképen érdekes módon mindhárom, valaha létezett tó vízjárta területként, de nem tóként szerepel. ${ }^{46}$ Mindkét, ma is létező tó először az 1980-as években tünik fel. ${ }^{47}$

Az összefüggést az 1518-ban említett, a simontornyai barátoknak adományozott tavak és a ma is létező, beszédes nevü halastó között jól megörizte a hagyomány, és az ezt feldolgozó helytörténészek, mégsem az oklevél szövegéből indultak ki a tavak középkori hovatartozását illetően. Kiss István müvének két részletéből ugyan mindez kikövetkeztethető, hiszen elöször - mint idéztük - (a defterekben Barátszékelynek mondott) ${ }^{48}$ Kisszékely kapcsán arról ír, hogy „itt két ma is létezö halastavat” kaptak a domonkosok, ${ }^{49}$ később pedig az 1518-as adomány kapcsán ismét említi a tavakat, ugyanakkor helyüket itt már Tömörkény-pusztára teszi, amelyet a mai Csókáspusztával azonosít. ${ }^{50}$ Talán ennek nyomán olvashatjuk ma már egyes munkákban, hogy Buzlai Mózes a szerzeteseket „Csókás pusztával és két halastóval ajándékozta meg". ${ }^{51}$ Tény, hogy Temerkény falu régészeti nyomai valóban a mai Csókáspuszta közelében fekszenek, ugyanakkor a mai - a 18. század vége óta észak felé hosszan terjeszkedő - Kisszékely északi széléhez igen közel. Kiss István vélhetőleg ismerhette a falu helyét - könyvében egyébként több elpusztult faluhelyet is megörökít ${ }^{52}-$, hiszen másképpen nem magyarázható, miért éppen Csókáspusztával azonosította Temerkényt. Hazánkban eddig föként ciszterci és pálos kolostorok környezetében sikerült középkori halastavakat azonosítani, most egy későközépkori domonkos kolostor két középkori halastavára mutattunk rá. Sok új eredményt talán nem hoztunk, mindössze arra mutattunk rá, hogy a helynévmagyarázó hagyománynak és a nyomán járó helytörténészeknek a maguk módján igazuk volt, de mégsem vizsgálták meg a halastavakra vonatkozó eredeti írott forrást, valamint a ma is létező tó tájrégészeti elemeit, ezért nem mutathattak rá a tavak és Temerkény falu közötti összefüggésre, amelyet immár régészetileg is sikerült azonosítani. Összefoglalásul elmondhatjuk, hogy a tavakra vonatkozó, ismeretlen eredetü hagyomány egybevág az írott forrásokkal (hacsak nem éppen onnan ered), és 18. századi térképes adatok, valamint a tó partján azonosított régészeti lelöhely alapján is igazolható valóságtartalma. Ezek révén újabb, középkori eredetű halastavat - sőt, a Csádés-tóval kiegészítve inkább fejlett kolostori

\footnotetext{
${ }^{42}$ http://archivportal.arcanum.hu/maps/html/katfelm2b_google.html [a megtekintés időpontja: 2012. november 30.]

${ }^{43} \mathrm{http}$ //www.archivportal.arcanum.hu/kataszter/ [a megtekintés időpontja: 2012. november 30.]

44 1950: L-34-38-C-c.

45 TMFN 1981, 90: 10/8.

46 1977: L-34-38-C-c.

47 1986: EOV 34-232. A térképek összegyüjtve: CZIMONDOR é. n., 28-32.

${ }^{48}$ A csupán Velics Antal és Kammerer Ernő munkájában (VELICS - KAMMERER 1890, II. 441.) szereplő Barátszékely (Beraten-Szigel) név talán téves olvasat eredménye, hiszen - mint Dávid Géza figyelmeztet - „e munka használhatóságát erősen csökkenti jó néhány rosszul olvasott hely- és személynév”. DÁVID 1982, 13. 20. jegyzet Szintén erre utal, hogy Kisszékely a simontornyai szandzsák deftereiben mindvégig következetesen Paraszt-Székel formában szerepel (uo. 128), Dávid Géza pedig - baráti közlése szerint - könyvében minden, a defterekben szereplö névvariánst felsorolt. A falunak ráadásul a középkorban sem volt szerzetesrendi birtokosa, a simontornyai váruradalomhoz tartozott. CSÁNKI 1897, 450.

${ }^{49}$ KISS 1938, 74.

${ }^{50}$ KISS 1938, 268

${ }^{51}$ CZIMONDOR é. n., 22; http://kisszekely.varosatyak.hu/ [a letöltés időpontja: 2012. november 16.]

${ }^{52}$ Munkájára részletesen: TÓTHNÉ UNGHY 2004, 33-42.
} 
gazdálkodásra utaló komplex halastórendszert (3. ábra) - tarthatunk számon Tolna megyében, ${ }^{53}$ ami jelentős eredmény annak fényében, hogy a térségben máig kérdéses számos középkori település fekvése is.

\footnotetext{
${ }^{53}$ Ezekre: FERENCZI 2008, 350-351; ZATYKÓ 2011, 402.
} 


\section{Képek}

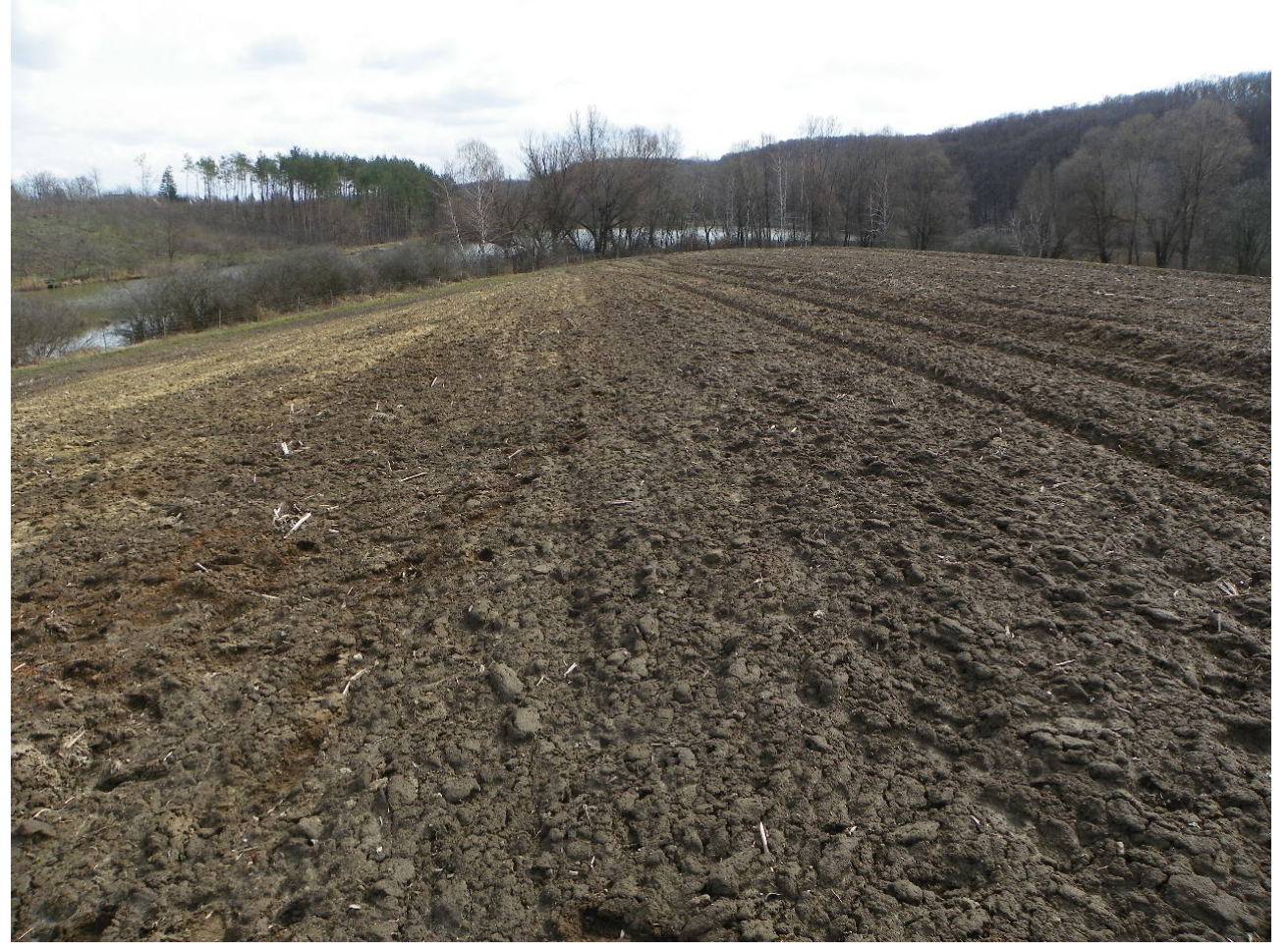

1. ábra: középkori eredetű mélyút a Barátok tava gátján vezető út folytatásában

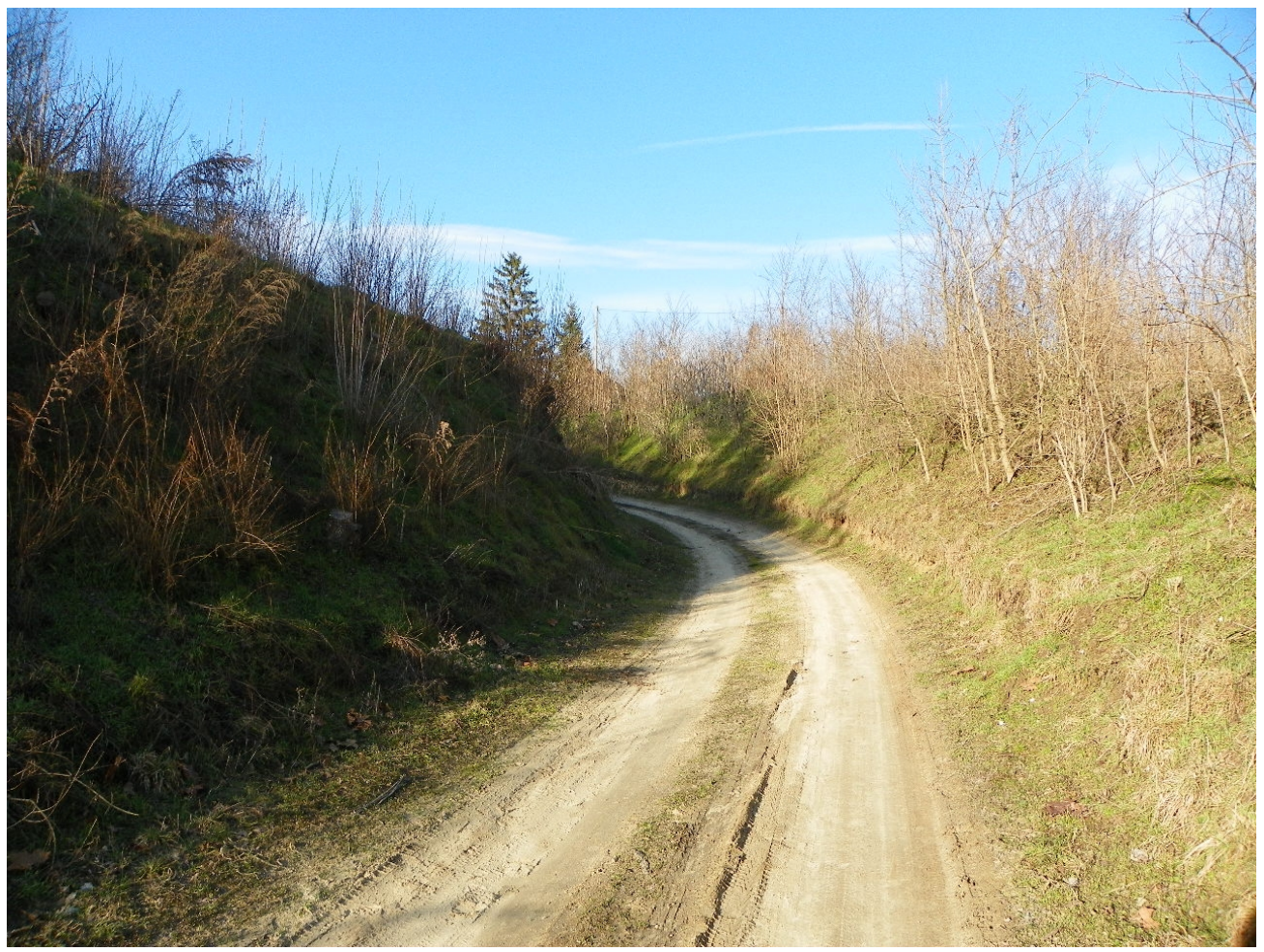

2. ábra: Temerkény falu helye a Barátok tava két ága által közrefogott földnyelven 


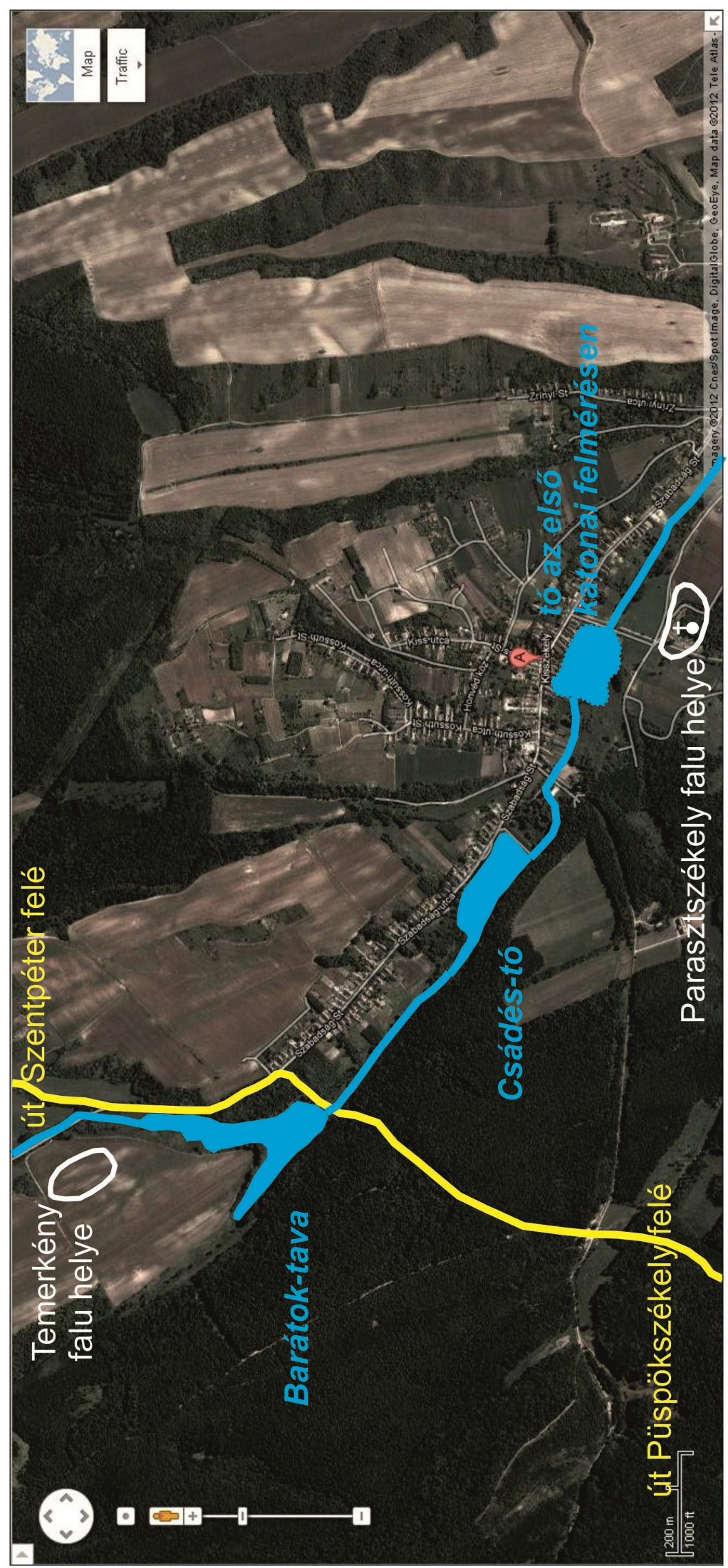

3. ábra: a Barátok tava és környezete, a közleményben említett középkori objektumokkal (forrás: maps.google.hu 


\section{IRODALOM}

$\mathrm{AO}$

AOkl

1883 Nagy Imre (szerk.): Anjoukori okmánytár. III. Bp.

2004 Kristó Gyula-Makk Ferenc (szerk.): Anjou-kori oklevéltár. XIX. Bp.-Szeged.

C. TÓTH N.

2000 Források Simontornya középkori történetéhez. Levéltári Közlemények 71, 93 137.

CZIMONDOR K.

é. n. Kisszékely-Nagyszékely építészeti örökségének védelme. Szent István Egyetem Ybl Miklós Építéstudományi Kar. Tudományos Diákkör. http://mnvh.hu/ptPortal/index.php?mod=news\&action=showNews\&newsid=11

CSÁNKI D. 901\&lang=hu [a letöltés időpontja: 2012. november 16.]

1897 Magyarország történelmi földrajza a Hunyadiak korában. III. Bp.

DÁVID G.

1982 A simontornyai szandzsák a 16. században. Bp.

$\mathrm{EKF}$

2004 Jankó Annamária-Oross András (közremük.): Az első katonai felmérés: a Magyar Királyság teljes területe 965 nagyfelbontású színes térképszelvényen, 1782-1785. DVD-ROM. Bp.

ENGEL P.

2001 Magyarország a középkori végén. Digitális térkép és adatbázis a középkori FEJÉR, GY. Magyar Királyság településeiről. CD-ROM. Bp.

1834-1843 Codex diplomaticus Hungariae ecclesiasticus ac civilis. Tomi IX. Vol. 3, Tomi X. Vol. 7. Buda

FERENCZI L.

2008 Vízgazdálkodás a középkori Magyarországon. In: Kubinyi AndrásLaszlovszky József-Szabó Péter (szerk.): Gazdaság és gazdálkodás a középkori GAÁL A.-KÖHEGYI M. Magyarországon. Gazdaságtörténet, anyagi kultúra, régészet. Bp. 341-361.

1975 Tolna megye Pesty Frigyes Helynévtárában. II. Balogh Ádám Múzeum Évkönyve 4-5 (1973-74) 297-339.

GYÖRFFY E.

2010 A folyóvíznevek kronológiai és területi állandósága. Helynévtörténeti Tanulmányok 5, 129-137.

HARSÁNYI A.

KISS I.

1938 A domokosrend Magyarországon a reformáció előtt. Debrecen

KISS L.

1938 Simontornya krónikája. Simontornya

K. NÉMETH A.

1998 Földrajzi nevek etimológiai szótára. I-II. Bp.

2002 Bántava. Egy Tolna megyei dülőnév középkori eredetéről. Magyar Nyelvőr 126, 500-502.

2011 A középkori Tolna megye templomai. Pécs

LANGÓ P. 
2006 Régészeti és okleveles adatok a Jászság 10-15. századi településtörténetéhez (Archaeological and charter data for the Jazygian settlemental history int he 1015th century). Tisicum 15, 77-97.

MIKESY S.

1940 Szabolcs vármegye középkori víznevei. Bp. (A Magyar Nyelvtudományi Társaság kiadványai 53.)

MNL

1981 Ortutay Gyula (föszerk.): Magyar Néprajzi Lexikon. IV. Bp.

MOL

MREV

Magyar Országos Levéltár

1908 Római Magyar Történeti Intézet (közrebocsájtja): Monumenta Romana episcopatus Vesprimiensis. A veszprémi püspökség római oklevéltára. IV. Bp.

TESZ

1967-1976 Benkő Loránd (föszerk.): A magyar nyelv történeti etimológiai szótára. I-III. Bp.

TMFN

1981 Végh József-Ördög Ferenc-Papp László (szerk.): Tolna megye földrajzi nevei. Bp.

TÓTHNÉ UNGHY I.

2004 A krónikaíró dr. Kiss István élete és munkássága. Simontornya

ÚMTSz

1979 B. Lőrinczy Éva (főszerk.): Új magyar tájszótár. I. Bp.

VELICS A.-KAMMERER E.

1890 Magyarországi török kincstári defterek. II. Bp.

ZATYKÓ, Cs.

2011 Aspects of fishing in medieval Hungary. In: Jan Klapste-Petr Sommer (eds.):

Processing, Storage, Distribution of Food. Food in the Medieval Rural Environment. Brepols 399-408. (Ruralia VIII.)

$\mathrm{ZsO}$

Mályusz Elemér (összeáll.): Zsigmondkori oklevéltár. I. Bp. 1951; Borsa Iván (Mályusz Elemér kéziratát kieg. és szerk.): Zsigmondkori oklevéltár VIII. Bp. 2001. 


\title{
BARÁTOK TAVA (TEICH DER MÖNCHE) \\ LANDSCHAFTSARCHÄOLOGISCHE UND HISTORISCHE ANGABEN ZUM URSPRUNG EINES GEOGRAFISCHEN NAMENS
}

\author{
András K. Németh
}

Die Mitteilung erklärt den Ursprung des Namens des in der Gemarkung von Kisszékely im Kom. Tolna befindlichen Barátok tava („Teich der Mönche“) mit Hilfe landschaftsarchäologischer und historischer Angaben. Gemäß einer Angabe von 1518 erhielt das Dominikanerkloster von Simontornya zwei Fischteiche in der Puszta Temerkény. Der beim Barátok tava unlängst entdeckte Ort eines mittelalterlichen Dorfes konnte aufgrund urkundlicher Angaben als das verödete Temerkény identifiziert werden. So ist anzunehmen, dass der Barátok tava und der Csádés-tó in seiner Nähe die beiden den dominikanischen „Brüdern“ von Simontornya geschenkten Fischteiche gewesen sein können. 